\title{
PENGARUH MORAL, FREKUENSI PELATIHAN PELAPORAN PERPAJAKAN, DAN NORMA SUBJEKTIF TERHADAP KEPATUHAN PAJAK MELALUI PEMAHAMAN AKUNTANSI PADA PELAKU USAHA MIKRO KPP PRATAMA CILEGON
}

\author{
Dadan Ramdhani ${ }^{1}$, Wahyu Yulianto Wibowo ${ }^{2}$, Popong Suryani ${ }^{3}$ dan Bima Prabowo ${ }^{4}$ \\ Fakultas Ekonomi dan Bisnis, Universitas Sultan Ageng Tirtayasa ${ }^{1,4}$ \\ STIE Putera Perdana Indonesia ${ }^{2,3}$ \\ E-mail: ddn_ramdhani@yahoo.com
}

\begin{abstract}
This research of this study was to examine the effect of morale, frequency of tax reporting training, and subjective norms againts tax compliance through understanding accounting. This research was carried out at Kantor Pelayanan Pajak (KPP) Pratama Cilegon. This study uses primary data obtained from the questionnaire. The sample used in this study is a Micro, Small and Medium Enterprises Taxpayers registered at KPP Pratama Cilegon. The sampling technique used is purposive sampling. 145 questionnaires were distributed, and 145 questionnaires were returned. Data were analyzed using Statistical Product and Service Solution (SPSS) version 23. The results of this study indicate that morale, subjective norms and understanding of accounting have a significant effect on tax compliance, while the frequency of tax reporting training does not affect tax compliance. Morale and subjective norms do not affect the understanding of accounting, while the frequency of tax reporting training influences the understanding of accounting. Morale, frequency of tax reporting training, and subjective norms have no effect againts tax compliance through understanding accounting.
\end{abstract}

Keywords : Morale, Frequency of Tax Reporting Training, Subjective Norms, Understanding of Accounting, and Tax Compliance

\section{Pendahuluan}

Sumber penerimaan negara hampir seluruhnya berasal dari penerimaan pajak. Pajak menjadi salah satu sumber penerimaan negara yang dinilai efektif yang memiliki peranan strategis dalam meningkatkan kemakmuran dan kesejahteraan bangsa. Untuk itu peran pajak perlu ditingkatkan secara optimal guna mempercepat laju pertumbuhan di Indonesia. Kepatuhan pajak merupakan problematika perpajakan. Di Indonesia rasio kepatuhan Wajib Pajak dalam melaksanakan kewajiban perpajakannya masih di bawah ekspektasi.

Akar permasalahan perpajakan di Indonesia sebagian masyarakat belum sepenuhnya menjadi Wajib Pajak, sedangkan yang telah terdaftar sebagai Wajib Pajak masih banyak yang tidak mau melaporkan pajaknya apalagi untuk membayar pajak. Berdasarkan informasi dari Direktorat Jenderal Pajak (DJP) menunjukkan bahwa jumlah Wajib Pajak yang terdaftar per 1 Januari 2018 sebanyak 39,2 juta atau 14,9\% dari populasi penduduk Indonesia yang berjumlah 261,8 juta jiwa berdasarkan data Badan Pusat Statistik (BPS) tahun 2017. Dari data tersebut menunjukkan bahwa jumlah Wajib Pajak masih belum ideal.Kontribusi penerimaan pajak sebagian besar berasal dari Wajib Pajak besar. Sebagaimana data dari Direktorat Jenderal Pajak (DJP) pada tahun 2018, realisasi penerimaan pajak Kanwil DJP Wajib Pajak besar mencapai Rp 418,73 triliun, dengan berkontribusi sebesar 31,8\% dari total penerimaan pajak tahun 2018 yang mencapai Rp 1.577,56 triliun. Berdasarkan data yang dirilis Jawa Pos pada 23 Juni 2018, Direktur Penyuluhan, Pelayanan, dan Humas Ditjen Pajak 
Kementerian Keuangan, Hestu Yoga Saksama, menyampaikan bahwa kontribusi UMKM terhadap Produk Domestik Bruto (PDB) Indonesia sebesar 60 persen. Namun komponen PPh final UMKM terhadap tax ratio amat kecil. Hal ini tergambar dari total penerimaan $\mathrm{PPh}$ di sektor UMKM tahun 2017 yang hanya Rp 5,9 triliun.

Pertimbangan kepatuhan pajak tidak hanya didasarkan oleh faktor ekonomi, tetapi juga faktor non ekonomi. Dalam hal ini faktor non ekonomi yang dimaksud adalah moral pajak (tax morale). Pendekatan moral pajak merupakan alternatif kebijakan di tengah keterbatasan pendekatan ekonomi. Kepatuhan pajak didorong tidak hanya sebagai akibat dari tindakan pengawasan, tetapi juga hasil dari internalisasi pajak sebagai norma sosial di masyarakat. Dalam penerapannya, moral pajak dipengaruhi tiga faktor utama. Masing-masing adalah aturan moral, sistem pajak yang adil, dan hubungan Wajib Pajak dengan pemerintah.

Sosialisasi perpajakan merupakan hal yang penting dalam meningkatkan kepatuhan Wajib Pajak, dalam hal ini dapat berupa pelatihan pelaporan perpajakan. Pelatihan pelaporan perpajakan sangat dibutuhkan khususnya untuk Wajib Pajak yang menjalankan usaha untuk meningkatkan pengetahuan perpajakannya Pengetahuan pajak mengacu pada proses, di mana pembayar pajak menjadi sadar akan peraturan pajak dan informasi terkait pajak lainnya (Oladipupo dan Obazee, 2016).

Norma subjektif memiliki peran penting dalam memotivasi atau mendorong kepatuhan Wajib Pajak. Presiden International Tax and Investment Center (ITIC), Daniel Witt, dikutip dari CNN Indonesia pada 9 Oktober 2018, mengatakan bahwa langkah pendekatan tekanan sosial akan efektif jika masyarakat sedari awal punya kesadaran untuk membayar pajak. Disamping itu, norma subjektif berupa motivasi atau dorongan dari lingkungan tempat tinggal berperan untuk meningkatkan kesadaran dalam menjalankan kewajiban perpajakan.

Pemahaman tentang akuntansi juga menjadi bagian penting dari kepatuhan dalam membayar pajak. Dengan memahami cara pencatatan yang benar, khususnya pada pengusaha dapat mengukur tingkat pendapatan dan pengeluaran dari usaha yang dijalankan, sehingga para pengusaha mengetahui keuntungan dalam usahanya dengan tepat, dan para pengusaha dapat menghitung pajak yang akan disetorkan dengan benar. Pemahaman ketentuan dalam perpajakan penting karena dengan memahami ketentuan dalam perpajakan maka pengusaha tahu tata cara membayar pajak yang benar dan tepat.

Potensi pajak yang ada hingga saat ini belum dapat terpenuhi secara optimal. Dikarenakan masih banyak Wajib Pajak yang belum memiliki kesadaran akan pentingnya kewajiban perpajakan baik bagi negara maupun bagi dirinya sendiri. Berikut pelaporan SPT di KPP Pratama Cilegon:

Tabel 1

Pelaporan SPT di KPP Pratama Cilegon

\begin{tabular}{|l|r|r|r|}
\hline Tahun & $\begin{array}{c}\text { Jumlah Wajib } \\
\text { Pajak UMKM } \\
\text { Terdaftar }\end{array}$ & $\begin{array}{c}\text { Wajib Pajak } \\
\text { UMKM Lapor } \\
\text { SPT }\end{array}$ & $\begin{array}{c}\text { Persentase } \\
\text { RasioKepatu } \\
\text { han }\end{array}$ \\
\hline 2014 & 247 & 35 & $14,17 \%$ \\
\hline 2015 & 526 & 119 & $22,62 \%$ \\
\hline 2016 & 856 & 189 & $21,14 \%$ \\
\hline 2017 & 1.333 & 149 & $10,80 \%$ \\
\hline
\end{tabular}

Sumber : KPP Pratama Cilegon (2019)

Tabel di atas menunjukkan setiap tahunnya jumlah pelaku UMKM yang terdaftar sebagai Wajib Pajak UMKM selalu meningkat. Namun tidak berimbang dengan persentase rasio kepatuhan Wajib Pajak UMKM dalam menjalankan kewajiban perpajakannya. Dalam tabel di atas menunjukkan persentase rasio kepatuhan mengalami peningkatan pada tahun 
2015 menjadi $22,62 \%$ dari $14,17 \%$ pada tahun 2014. Pada tahun 2016 persentase rasio kepatuhan tercatat sebesar $21,14 \%$ dan pada tahun 2017 menurun menjadi 10,80\%. Berdasarkan data dari KPP Pratama Cilegon jumlah UMKM yang tercatat sebagai Wajib Pajak UMKM hingga tahun 2017 mencapai 1.333 pelaku UMKM, tidak setara dengan data dari Pusat Inkubator Wirausaha dan Klinik UKM (PIWKU) yang menunjukkan bahwa jumlah UMKM di Kota Cilegon hingga 2017 mencapai 4.367 pelaku UMKM. Hal ini menunjukkan bahwa masih rendahnya kesadaran pelaku UMKM dalam menjalankan perpajakan.

\section{Tinjauan Literatur dan Pengembangan Hipotesis}

Theory Planned Behavior. Teori ini menjelaskan bahwa perilaku yang ditimbulkan oleh individu timbul karena adanya niat untuk melakukan perilaku. Astuti dan Panjaitan (2018) menyatakan munculnya niat untuk berperilaku ditentukan oleh tiga faktor. Pertama, Behavioral Beliefs merupakan keyakinan individu mengenai hasil dari suatu perilaku dan evaluasi akan hasil yang diperoleh. Kedua, Normative beliefs merupakan keyakinan mengenai harapan normatif orang lain dan memiliki motivasi yang tinggi untuk memenuhi harapan tersebut. Ketiga, Control beliefs merupakan keyakinan mengenai keberadaan sesuatu hal yang mendukung atau menghambat tindakan yang akan ditampilkan dan persepsinya tentang seberapa besar sesuatu hal yang mendukung dan menghambat tindakannya tersebut (Perceived Power). Sedangkan teori yang melandasi kepatuhan pajak menurut Sani dan Habibie (2017) yaitu Attribution theory, persepsi seseornag untuk membuat penilaian mengenai orang lain sangat dipengaruhi oleh konsisi internal dan eksternal.

Menurut Rahayu (2013: 138) mengatakan bahwa, kepatuhan perpajakan dapat didefinisikan sebagai suatu keadaan dimana Wajib Pajak memenuhi semua kewajiban perpajakan dan melaksanakan hak perpajakan. Dalam hubungannya dengan Wajib Pajak yang patuh, maka pengertian kepatuhan Wajib Pajak merupakan suatu ketaatan Wajib Pajak untuk melakukan ketentuan-ketentuan atau aturan-aturan perpajakan yang diwajibkan atau diharuskan untuk dilaksanakan (Mandagi dkk., 2014: 1667).Pada prinsipnya kepatuhan Wajib Pajak adalah tindakan Wajib Pajak dalam pemenuhan kewajiban perpajakannya sesuai dengan ketentuan peraturan perundang-undangan dan peraturan pelaksanaan perpajakan yang berlaku dalam suatu negara. (Rahayu, 2013:139).

Astuti dan Panjaitan (2018: 60) menyatakan bahwa moral pajak merupakan determinan kunci yang dapat menjelaskan mengapa orang jujur dalam masalah perpajakan. Wajib Pajak yang lebih menggunakan moral dalam pengambilan keputusan pembayaran pajak akan lebih patuh dibandingkan dengan Wajib Pajak lainya. Wajib Pajak dengan tingkat moral yang sama tetapi memiliki persepsi yang berbeda akan memiliki reaksi yang berbeda terhadap kepatuhan pajak (Sani dan Habibie, 2017: 82).Penelitian terdahulu yang dilakukan oleh Tri Astuti dan Inggrid Panjaitan (2018), Adrian Chrissanjaya (2018), menunjukkan bahwa moral berpengaruh signifikan terhadap kepatuhan pajak.

Sosialisasi perpajakan berfungsi meningkatkan pengetahuan perpajakan Wajib Pajak. Pengetahuan perpajakan adalah proses pengubah sikap dan tata laku wajib pajak atau kelompok wajib pajak dalam usaha mendewasakan manusia melalui upaya pelatihan (Anwar, 2015: 6). Direktorat Jenderal Pajak (DJP) selalu berupaya mengoptimalkan pelayanannya supaya Wajib Pajak selalu melaksanakan kewajibannya. Dalam hal ini melalui DJP melalui Kantor Pelayanan Pajak (KPP) diantaranya dengan memberikan pelatihan pelaporan perpajakan. Penelitian terdahulu yang dilakukan oleh Adiatma, Handayani, dan Hidayat (2015) yang menunjukkan bahwa edukasi berpengaruh signifikan terhadap kepatuhan Wajib Pajak. Penelitian tersebut didukung oleh penelitian Ardy, Kristanto, dan Damayanti (2018) menunjukkan bahwa tax socialization (sosialisasi pajak) berpengaruh positif dan signifikan 
terhadap tax compliance (kepatuhan pajak). Serta penelitian oleh Wicaksono, Nazar, dan Kurnia (2018) menunjukkan bahwa pengetahuan Wajib Pajak mempunyai hubungan dan berpengaruh signifikan positif terhadap kepatuhan Wajib Pajak OP non karyawan.

Gambar 1

Kerangka Pemikiran

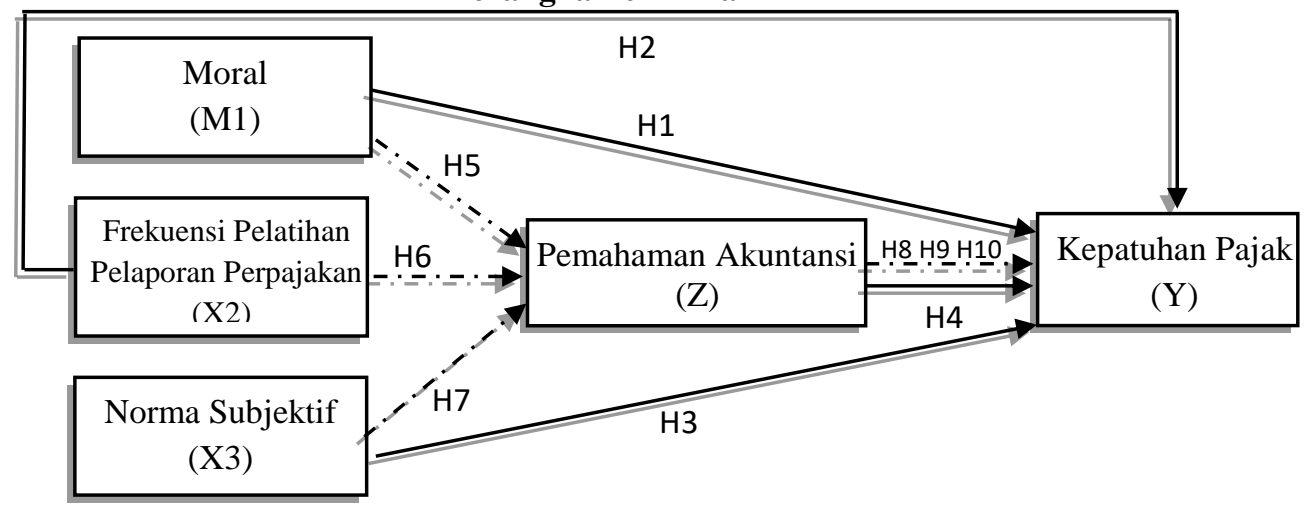

Sumber:Jap (2018), Astuti dan Panjaitan (2018), Ardy dkk. (2018),Sani dan Habibie (2017)

Dari gambar di atas dapat dilihat bahwa terdapat tiga variabel independen yakni moral (X1), frekuensi pelatihan pelaporan perpajakan (X2), dan norma subjektif (X3). Pemahaman akuntansi $(\mathrm{Z})$ sebagai variabel intervening. Sedangkan variabel dependen adalah kepatuhan pajak (Y).Berdasarkan pembahasan dan gambar diatas, maka dapat diperoleh hipotesis sebagai berikut: (1) hipotesis pertama adalah moral berpengaruh terhadap kepatuhan pajak, (2) hipotesis kedua adalah frekuensi pelatihan pelaporan perpajakan berpengaruh terhadap kepatuhan pajak, (3) hipotesis ketiga adalah norma subjektif berpengaruh terhadap kepatuhan pajak, (4) hipotesis keempat adalah pemahaman akuntansi berpengaruh terhadap kepatuhan pajak. (5) hipotesis kelima adalah moral berpengaruh terhadap pemahaman akuntansi. (6) hipotesis keenam adalah frekuensi pelatihan pelaporan perpajakan berpengaruh terhadap pemahaman akuntansi. (7) hipotesis ketujuh adalah norma subjektif berpengaruh terhadap pemahaman akuntansi. (8) hipotesis kedelapan adalah moral berpengaruh terhadap kepatuhan pajak melaluipemahaman akuntansi. (9) hipotesis kesembilan adalah frekuensi pelatihan pelaporan perpajakan berpengaruh terhadap kepatuhan pajak melaluipemahaman akuntansi.(10) hipotesis kesepuluh adalah norma subjektif berpengaruh terhadap kepatuhan pajak melaluipemahaman akuntansi.

\section{Metode Penelitian}

Populasi adalah wilayah generalisasi yang terdiri atas obyek atau subyek yang mempunyai kualitas dan karakteristik tertentu yang ditetapkan oleh peneliti untuk dipelajari dan kemudian ditarik kesimpulannya (Sugiyono, 2015: 8).Populasi dalam penelitian ini adalah pelaku UMKM yang terdaftar sebagai Wajib Pajak di KPP Pratama Cilegon. Jumlah populasi dalam penelitian ini sebanyak 1.333Wajib Pajak UMKM.

Sampel yang akan digunakan dalam penelitian ini adalah Wajib Pajak UMKM yang terdaftar di KPP Pratama Cilegon.. Dalam penelitian ini, teknik pengambilan sampel menggunakan metode purposive sampling, yaitu cara penarikan atau pengambilan sampel yang dilakukan untuk memilih subjek berdasarkan kriteria spesifik yang ditetapkan oleh peneliti. Kriteria yang ditetapkan oleh penliti yaitu Wajib Pajak UMKM dengan omzet dibawah RP 4,8 miliar dalam satu tahun. Yang terdaftar di KPP Pratana Cilegon. Penentuan jumlah sampel menggunakan rumus slovin, perumusan rumus sampel dirumuskan sebagai berikut: 


$$
\begin{aligned}
& \mathrm{n}=\frac{\mathrm{N}}{1+\mathrm{N}(\mathrm{e})^{2}} \\
& \mathrm{n}=\frac{1.333}{1+1.333(10 \% 6)^{2}} \\
& \mathrm{n}=93,02 \text { dibulatkan menjadi } 100
\end{aligned}
$$

\author{
Ket: $\mathrm{n}=$ jumlah anggota sampel \\ $\mathrm{N}=$ jumlah anggota populasi \\ $\mathrm{e}=$ nilai kritis $($ batas kesalahan 0,05$)$
}

\begin{tabular}{|c|c|c|c|}
\hline No. & Variabel & Definisi & Indikator \\
\hline \multicolumn{4}{|c|}{ Variabel Dependen } \\
\hline 1 & $\begin{array}{l}\text { Kepatuhan } \\
\text { Pajak (Y) }\end{array}$ & $\begin{array}{l}\text { Kepatuhan pajak adalah tunduk, taat dan } \\
\text { patuhnya Wajib Pajak dalam } \\
\text { melaksanakan hak dan kewajiban } \\
\text { perpajakannya sesuai dengan undang- } \\
\text { undang } \quad \text { perpajakan r yang } \\
\text { berlaku(Rahayu, 2013: 138) }\end{array}$ & $\begin{array}{l}\text { Kepatuhan Wajib Pajak untuk } \\
\text { melaporkan atau mendaftarkan diri ke } \\
\text { kantor pajak } \\
\text { Kepatuhan dalam melaporkan SPT } \\
\text { tepat waktu tidak sampai tertinggal. } \\
\text { Kepatuhan dalam menghitung dan } \\
\text { membayar pajak dengan benar, } \\
\text { lengkap dan sesuai standar. } \\
\text { Kepatuhan dalam membayar } \\
\text { tunggakan pajak yang tersisa. } \\
\text { Kepatuhan atas peraturan perpajakan } \\
\text { dan perundang undangan. } \\
\text { (Astuti dan Panjaitan 2018) }\end{array}$ \\
\hline \multicolumn{4}{|c|}{ Variabel Intervening } \\
\hline 2 & $\begin{array}{l}\text { Pemahaman } \\
\text { Akuntansi (Z) }\end{array}$ & $\begin{array}{l}\text { Pemahaman akuntansi merupakan } \\
\text { tingkat seseorang untuk mengenal dan } \\
\text { mengerti tentang akuntansi (Artana, } \\
\text { 2014: 4). }\end{array}$ & $\begin{array}{l}\text { Pemahaman dalam pencatatan } \\
\text { transaksikeuangan } \\
\text { Mengelompokkan transaksi dengan } \\
\text { benar } \\
\text { Memahami tahap pengikhtisaran data } \\
\text { keuangan } \\
\text { Dapat menyusun laporan keuangan } \\
\text { secara sistematis } \\
\text { Dapat menafsirkan data } \\
\text { keuangan.(Pakpahan, 2015, Sani dan } \\
\text { Habibie 2017) }\end{array}$ \\
\hline \multicolumn{4}{|c|}{ Variabel Independen } \\
\hline 3 & Moral (X1) & $\begin{array}{l}\text { Moral pajak adalah motivasi intrinsik } \\
\text { yang dimiliki seseorang atau badan } \\
\text { untuk mematuhi dan membayar pajak } \\
\text { sehingga berkontribusi secara sukarela } \\
\text { pada penyediaan barang-barang } \\
\text { publik.(Torgler, dalam Astuti dan } \\
\text { Panjaitan, 2018: 60) }\end{array}$ & $\begin{array}{l}\text { Kebanggaan Nasional } \\
\text { Kepercayaan pada instansi pemerintah } \\
\text { Kondisi ekonomi } \\
\text { Sistem perpajakan } \\
\text { Sanksi administrasi dan pemeriksaan } \\
\text { pajak } \\
(\text { Fella, 2014) }\end{array}$ \\
\hline 4 & $\begin{array}{l}\text { Frekuensi } \\
\text { Pelatihan } \\
\text { Pelaporan } \\
\text { Perpajakan } \\
\text { (X2) }\end{array}$ & $\begin{array}{l}\text { Frekuensi dapat diartikan sebagai tingkat } \\
\text { keseringan. Pelatihan merupakan } \\
\text { serangkaian aktivitas individu dalam } \\
\text { meningkatkan keahlian dan pengetahuan } \\
\text { secara sistemastis sehingga mampu } \\
\text { memiliki kinerja yang professional di } \\
\text { bidangnya Pelaporan pajak merupakan } \\
\text { tahapan ketiga dalam siklus hak dan } \\
\text { kewajiban Wajib Pajak. (Widodo, } \\
\text { 2015: 82). }\end{array}$ & $\begin{array}{l}\text { Pelaksanaan pelatihan pelaporan } \\
\text { perpajakan oleh Kantor Pelayanan } \\
\text { Pajak } \\
>\text { Pelayanan yang diberikan oleh petugas } \\
\text { pajak } \\
>\text { Pelatihan dalam memahami tata cara } \\
\text { perhitungan pajak } \\
\text { Pelatihan dalam memahami tata cara } \\
\text { pembayaran pajak } \\
\text { Pelatihan dalam memahami tata cara } \\
\text { pengisisan SPT } \\
\text { Pelatihan dalam memahami tata } \\
\text { cara penyampaian SPT } \\
\text { (Masruroh, 2013) }\end{array}$ \\
\hline
\end{tabular}

Tabel 2

Operasionalisasi Variabel 


\begin{tabular}{|c|c|c|c|}
\hline 5 & $\begin{array}{l}\text { Norma } \\
\text { Subjektif (X3) }\end{array}$ & $\begin{array}{l}\text { Norma subjektif adalah satu jenis } \\
\text { tertentu dari norma yang belum } \\
\text { mendapat banyak perhatian di bidang } \\
\text { kepatuhan pajak, yang didefinisikan } \\
\text { sebagai norma yang dimiliki oleh } \\
\text { individu yang berasal dari rujukan orang } \\
\text { lain (teman, keluarga, rekan kerja dekat) } \\
\text { tentang perilaku(Sani dan Habibie, } 2017 \\
\text { :83). }\end{array}$ & $\begin{array}{l}\text { Motivasi keluarga dalam mematuhi } \\
\text { ketentuan perpajakan } \\
\text { Motivasi teman dalam mematuhi } \\
\text { ketentuan perpajakan } \\
\text { Motivasi dari konsultan pajak untuk } \\
\text { mematuhi ketentuan perpajakan } \\
\text { Motivasi dari petugas pajakuntuk } \\
\text { mematuhi ketentuan perpajakan } \\
\text { Pengaruh media catak atau media } \\
\text { elektronik dalam mematuhi ketentuan } \\
\text { perpajakan } \\
\text { (Sani dan Habibie, 2017) }\end{array}$ \\
\hline
\end{tabular}

Sumber: Penelitian (2019)

Pengumpulan data yang dilakukan melalui kuesioner yang dijawab oleh responden, yaitu Wajib Pajak UMKM di KPP Pratama Cilegon. Pertanyaan dalam kuesioner dirancang dengan format sederhana dan mudah dipahami serta dilengkapi dengan petunjuk pengisian untuk membantu para wajib pajak dalam mengisi setiap data secara lengkap dan benar. Untuk memperoleh data sebenarnya, kuesioner di bagikan secara langsung kepada Wajib Pajak UMKM tersebut.Jenis data yang digunakan pada penelitian ini menggunakan data primer, yakni data untuk diperoleh secara langsung dari sumber asli (tidak melalui perantara). Pada penelitian ini, data primer diperoleh dari responden melalui kuesioner yang diberikan untuk Wajib Pajak UMKM di KPP PratamaCilegon. Sumber data dalam penelitian ini adalah melalui responden, yakni Wajib Pajak UMKM yang menjawab pernyataan penelitian secara tertulis dan dikembalikan ke peneliti.

Teknik analisis yang digunkan dalam penelitian anatara lain dengan analisis deskriptif. Lalu, uji kualitas data dengan menggunakan uji validitas dan reabilitas. Selanjtnya uji asumsi klasik yang terdiri dari normalitas, uji multikolinearitas, dan uji hesteroskedastisitas. Kemudian, Analisis regresi yang terdiri dari uji koefisien determinasi, uji f, dan uji t. Serta sobel test untuk menguji pengaruh variabel intervening.

Adapun model persamaan regresi sebagai berikut:

$$
\begin{aligned}
\mathrm{Z}(\text { PEMAHAMAN })= & \beta \text { MORAL }+\beta \text { FREKUENSI }+\beta \text { NORMA }+e_{1}(\text { Persamaan Struktural } 1) \\
\mathrm{Y}(\text { KEPATUHAN })= & \beta \text { MORAL }+\beta \text { FREKUENSI }+\beta \text { NORMA }+\beta \text { PEMAHAMAN }+e_{2} \text { (Persamaan } \\
& \text { Struktural } 2)
\end{aligned}
$$

\section{Hasil Penelitian dan Pembahasan}

Uji Kualitas Data. Untuk tingkat validitas dilakukan uji signifikansi dengan membandingkan nilai $r$ hitung dengan $r$ tabel. Untuk degree of freedom $(\mathrm{df})=\mathrm{n}-\mathrm{k}$ dalam hal ini $\mathrm{n}$ adalah jumlah sampel dan $\mathrm{k}$ adalah jumlah konstruk. Pada kasus ini besarnya df dapat dihitung 100-2 atau df = 98 dengan alpha 0,05 didapat $\mathrm{r}$ tabel 0,1966, jika $\mathrm{r}$ hitung (untuk tiap-tiap butir pertanyaan dapat dilihat pada kolom pearson correlation) lebih besar dari $r$ tabel dan nilai r positif, maka butir pertanyaan tersebut dikatakan valid.

Tabel 4

Hasil Uji Validitas

\begin{tabular}{|l|l|c|c|c|}
\hline Variabel & Item Pertanyaan & Pearson Corelation & r tabel & Keterangan \\
\hline \multirow{4}{*}{ Moral } & M1 & 0,690 & 0,1966 & Valid \\
\cline { 2 - 5 } & M2 & 0,743 & 0,1966 & Valid \\
\cline { 2 - 5 } & M3 & 0,694 & 0,1966 & Valid \\
\cline { 2 - 5 } & M4 & 0,664 & 0,1966 & Valid \\
\cline { 2 - 5 } & M5 & 0,634 & 0,1966 & Valid \\
\hline \multirow{3}{*}{$\begin{array}{l}\text { Frekuensi Pelatihaporan } \\
\text { Perpajakan }\end{array}$} & FPPP1 & 0,724 & 0,1966 & Valid \\
\cline { 2 - 5 } & FPPP2 & 0,790 & 0,1966 & Valid \\
\cline { 2 - 5 } & FPPP3 & 0,751 & 0,1966 & Valid \\
\cline { 2 - 5 } & FPPP4 & 0,659 & 0,1966 & Valid \\
\hline
\end{tabular}




\begin{tabular}{|c|c|c|c|c|}
\hline & FPPP5 & 0,764 & 0,1966 & Valid \\
\hline & FPPP6 & 0,662 & 0,1966 & Valid \\
\hline & FPPP7 & 0,790 & 0,1966 & Valid \\
\hline & FPPP8 & 0,778 & 0,1966 & Valid \\
\hline \multirow{5}{*}{ Norma Subjektif } & NS1 & 0,740 & 0,1966 & Valid \\
\hline & $\mathrm{NS} 2$ & 0,746 & 0,1966 & Valid \\
\hline & NS3 & 0,516 & 0,1966 & Valid \\
\hline & NS4 & 0,743 & 0,1966 & Valid \\
\hline & NS5 & 0,677 & 0,1966 & Valid \\
\hline \multirow{11}{*}{$\begin{array}{l}\text { Pemahaman } \\
\text { Akuntansi }\end{array}$} & PA1 & 0,748 & 0,1966 & Valid \\
\hline & PA2 & 0,715 & 0,1966 & Valid \\
\hline & PA3 & 0,694 & 0,1966 & Valid \\
\hline & PA4 & 0,645 & 0,1966 & Valid \\
\hline & PA5 & 0,739 & 0,1966 & Valid \\
\hline & PA6 & 0,723 & 0,1966 & Valid \\
\hline & PA7 & 0,757 & 0,1966 & Valid \\
\hline & PA8 & 0,757 & 0,1966 & Valid \\
\hline & PA9 & 0,502 & 0,1966 & Valid \\
\hline & PA10 & 0,527 & 0,1966 & Valid \\
\hline & PA11 & 0,542 & 0,1966 & Valid \\
\hline \multirow{12}{*}{ Kepatuhan Pajak } & KP1 & 0,553 & 0,1966 & Valid \\
\hline & KP2 & 0,481 & 0,1966 & Valid \\
\hline & KP3 & 0,624 & 0,1966 & Valid \\
\hline & KP4 & 0,686 & 0,1966 & Valid \\
\hline & KP5 & 0,691 & 0,1966 & Valid \\
\hline & KP6 & 0,626 & 0,1966 & Valid \\
\hline & KP7 & 0,688 & 0,1966 & Valid \\
\hline & KP8 & 0,544 & 0,1966 & Valid \\
\hline & KP9 & 0,520 & 0,1966 & Valid \\
\hline & KP10 & 0,580 & 0,1966 & Valid \\
\hline & KP11 & 0,567 & 0,1966 & Valid \\
\hline & KP12 & 0,629 & 0,1966 & Valid \\
\hline
\end{tabular}

Sumber: Data primer yang diolah, 2019

Data tabel 4 dapat diketahui bahwa masing-masing item pertanyaan memiliki $\mathrm{r}$ hitung $>\mathrm{r}$ tabel $(0,1966)$ dan bernilai positif. Dengan demikian butir pertanyaan tersebut dinyatakan valid.

Tabel 5

Hasil Uji Reabilitas

\begin{tabular}{|l|l|l|l|}
\hline Variabel & Reabilitas Coefficient & Alpha & Keterangan \\
\hline Moral Pelatihan & 5 item pertanyaan & 0,712 & Reliabel \\
\hline $\begin{array}{l}\text { Frekuensi item pertanyaan } \\
\text { Pelaporan Perpajakan }\end{array}$ & 0,872 & Reliabel \\
\hline Norma Subjektif & 5 item pertanyaan & 0,716 & Reliabel \\
\hline Pemahaman Akuntansi & 11 item pertanyaan & 0,879 & Reliabel \\
\hline Kepatuhan Pajak & 12 item pertanyaan & 0,838 & Reliabel \\
\hline
\end{tabular}

Sumber: Data primer yang diolah, 2019

Berdasarkan tabel 5 dapat diketahui bahwa masing-masing variabel memiliki Cronbach Alpha > 0,70. Dengan demikian variabel (moral, frekuensi pelatihan pelaporan perpajakan, norma subjektif, pemahaman akuntansi, dan kepatuhan pajak) dapat dikatakan reliabel atau andal.

Uji Asumsi Klasik. Uji normalitas data dalam penelitian ini dengan menggunakan grafik normal P-P Plot. Berikut merupakan hasil tampilan grafik normal P-P Plot: 

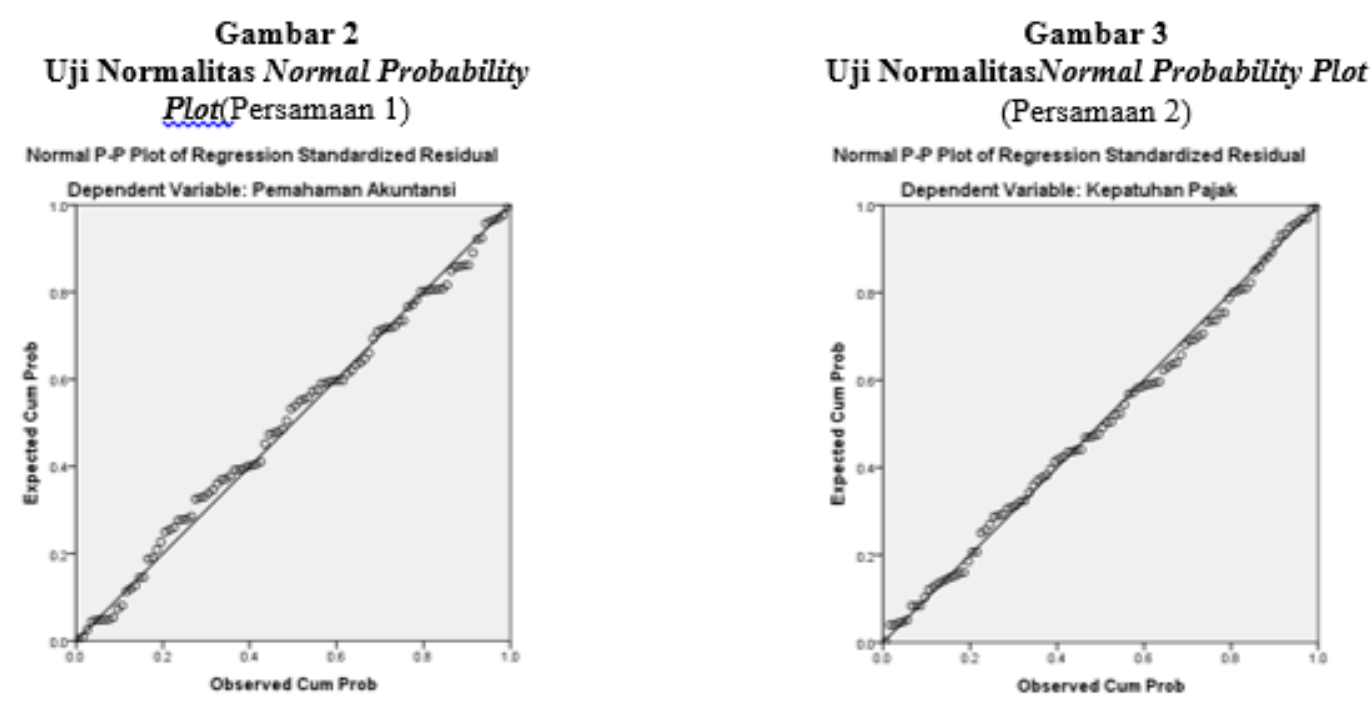

Sumber: Data primer yang diolah, 2019

Berdasarkan tampilan grafik normal P-P Plot pada kedua persamaan (gambar 4.2 dan gambar 4.3) di atas menunjukkan titik-titik menyebar di sekitar garis diagonal dan mengikuti arah garis diagonal tersebut, sehingga dapat disimpulkan bahwa data berdistribusi normal.

Uji multikolinearitas bertujuan untuk melihat ada atau tidaknya korelasi yang tinggi antara variabel-variabel independen dalam suatu model regresi linear berganda.

Tabel 6

Uji Multikolinearitas Tolerance dan VIF

\begin{tabular}{|l|l|l|l|l|}
\hline \multirow{2}{*}{ Model } & Persamaan 1 & \multicolumn{3}{l|}{ Persamaan 2 } \\
\cline { 2 - 5 } & Tolerance & VIF & Tolerance & VIF \\
\hline Moral & 0,699 & 1,431 & 0,694 & 1,440 \\
\hline $\begin{array}{l}\text { Frekuensi Pelatihan } \\
\text { Pelaporan Perpajakan }\end{array}$ & 0,643 & 1,556 & 0,611 & 1,638 \\
\hline Norma Subjektif & 0,669 & 1,494 & 0,645 & 1,550 \\
\hline Pemahaman Akuntansi & & & 0,790 & 1,266 \\
\hline
\end{tabular}

Sumber: Data primer yang diolah, 2019

Berdasarkan tabel 6 diketahui bahwa nilai tolerance pada variabel independen $>0,10$. Nilai variance inflation factor $(V I F)$ keempat variabel $<10$. Berdasarkan kriteria dalam pengambilan keputusan dapat disimpulkan bahwa tidak terjadi multikolinearitas.

Uji Heteroskedastisitas dalam penelitian ini menggunakan uji glejser. Model regresi yang baik adalah model regresi yang tidak terjadi heteroskedastisitas. Berikut merupakan rangkuman hasil uji glejser:

Tabel 7

Uji Heteroskedastisitas

\begin{tabular}{|l|l|l|}
\hline \multirow{2}{*}{ Model } & Persamaan 1 & Persamaan 2 \\
\cline { 2 - 3 } & Sig. & Sig. \\
\hline Moral Pelatihan & 0,917 & 0,956 \\
\hline $\begin{array}{l}\text { Frekuensi } \\
\text { Pelaporan Perpajakan }\end{array}$ & 0,385 & 0,442 \\
\hline Norma Subjektif & 0,106 & 0,633 \\
\hline Pemahaman Akuntansi & & 0,300 \\
\hline
\end{tabular}

Sumber: Data primer yang diolah, 2019 
Berdasarkan tabel 7, menunjukkan bahwa pada model regresi tidak terjadi gejala heteroskedastisitas. Hal ini karena masing-masing variabel dari kedua persamaan tersebut memiliki nilai probabilitas yang lebih besar dari nilai alpha (Sig. > 0.05).

\section{Analisis Regresi}

\section{Analisis Substruktural I}

$\mathrm{Z}(\mathrm{PEMAHAMAN})=\beta \mathrm{MORAL}+\beta$ FREKUENSI $+\beta$ NORMA $+e_{1}($ Persamaan Struktural 1$)$

Tabel 8

Pengaruh Moral, Frekuensi Pelatihan Pelaporan Perpajakan, dan Norma Subjektif Secara Simultan Terhadap Pemahaman Akuntansi

\begin{tabular}{|l|l|}
\hline Model & R Square \\
\hline & 0,210 \\
\hline
\end{tabular}

Sumber: Data diolah dari lampiran, 2019

Berdasarkan tabel 8 dapat diketahui bahwa nilai koefisien determinasi ditunjukkan dari besarnya angka $R$ Square $\left(\mathrm{R}^{2}\right)$ yang diperoleh adalah 0,210 . Hal ini dapat diartikan bahwa pengaruh variabel moral, frekuensi pelatihan pelaporan perpajakan, dan norma subjektif terhadap variabel pemahaman akuntansi secara simultan sebesar $21 \%$, sedangkan sisanya sebesar 79\% dipengaruhi oleh variabel lain di luar penelitian ini.

Untuk mengetahui kelayakan model regresi digambarkan angka-angka dari tabel ANOVA.

Tabel 9

ANOVA dengan nilai F dan Sig.

\begin{tabular}{|l|l|l|}
\hline Model & F & Sig. \\
\hline $\begin{array}{l}\text { Regression } \\
\text { Residual } \\
\text { Total }\end{array}$ & 8,499 & 0,000 \\
\hline
\end{tabular}

Sumber: Data diolah dari lampiran, 2019

Jika F-hitung > F-tabel, maka Ho ditolak dan Ha diterima dan sebaliknya F-hitung < Ftabel, maka Ho diterima dan Ha ditolak. Dari hasil uji F pada tabel 10, diperoleh angka Fhitung sebesar 8,499 > F-tabel sebesar 2,70 dan signifikan dengan signifikansi 0,000<0,05, sehingga Ho ditolak dan Ha diterima. Dengan demikian, model regresi tersebut sudah layak dan benar. Kesimpulannya adalah variabel moral, frekuensi pelatihan pelaporan perpajakan, dan norma subjektif mempunyai pengaruh yang signifikan secara simultan terhadap variabel pemahaman akuntansi.

Tabel 10

Pengaruh Moral, Frekuensi Pelatihan Pelaporan Perpajakan, dan Norma Subjektif Secara Parsial Terhadap PemahamanAkuntansi

\begin{tabular}{|l|l|l|l|}
\hline \multirow{2}{*}{ Model } & $\begin{array}{l}\text { Unstandardized } \\
\text { Coefficients }\end{array}$ & \multirow{2}{*}{$\mathrm{T}$} & \multirow{2}{*}{ Sig } \\
\cline { 2 - 3 } & Beta & 4,748 & 0,000 \\
\hline (Constant) & 21,518 & 0,777 & 0,439 \\
Moral & 0,182 & 5,244 & 0,027 \\
Frekuensi Pelatihan & 0,313 & 1,900 & 0,061 \\
Pelaporan Perpajakan & 0,399 & & \\
Norma Subjektif & & & \\
\hline
\end{tabular}

Sumber: Data diolah dari lampiran, 2019 
Jika t-hitung > t-tabel, maka Ho ditolak dan Ha diterima dan sebaliknya t-hitung < ttabel, maka Ho diterima dan Ha ditolak. Besarnya angka t-tabel dengan ketentuan $\alpha=0,05$ dan $\mathrm{df}=(\mathrm{n}-\mathrm{k})$ atau $(100-4)=96$. Dari ketentuan tersebut diperoleh angka t-tabel sebesar 1,98498. Berikut hasil uji t berdasarkan tabel 11:

Pengaruh Moral Terhadap Pemahaman Akuntansi Wajib Pajak UMKM. Berdasarkan hasil perhitungan, diperoleh angka t-hitung lebih kecil dari t-tabel $(0,777<1,98498)$, menjelaskan bahwa moral tidak berpengaruh terhadap pemahaman akuntansi Wajib Pajak UMKM. Angka signifikansi pada variabel moral sebesar 0,439>0,05. Atas dasar perbandingan tersebut, maka Ho diterima dan Ha ditolak, artinya variabel moral tidak mempunyai pengaruh yang signifikan terhadap pemahaman akuntansi Wajib Pajak UMKM, sehingga hipotesis kelima ditolak.

Pengaruh Frekuensi Pelatihan Pelaporan Perpajakan Terhadap Pemahaman Akuntansi Wajib Pajak UMKM. Berdasarkan hasil perhitungan, diperoleh angka t-hitung lebih besar dari t-tabel $(5,244>1,98498)$, menjelaskan bahwa frekuensi pelatihan pelaporan perpajakan berpengaruh terhadap pemahaman akuntansi Wajib Pajak UMKM. Angka signifikansi pada variabel frekuensi pelatihan pelaporan perpajakan sebesar 0,027<0,05. Atas dasar perbandingan tersebut, maka Ho ditolak dan Ha diterima, artinya variabel frekuensi pelatihan pelaporan perpajakan mempunyai pengaruh yang signifikan terhadap pemahaman akuntansi Wajib Pajak UMKM, sehingga hipotesis keenam diterima.

Pengaruh Norma Subjektif Terhadap Pemahaman Akuntansi Wajib Pajak UMKM. Berdasarkan hasil perhitungan, diperoleh angka t-hitung lebih kecil dari t-tabel $(1,900<$ 1,98498), menjelaskan bahwa norma subjektif tidak berpengaruh terhadap pemahaman akuntansi Wajib Pajak UMKM. Angka signifikansi pada variabel norma subjektif sebesar $0,061>0,05$. Atas dasar perbandingan tersebut, maka Ho diterima dan Ha ditolak, artinya variabel norma subjektif tidak mempunyai pengaruh yang signifikan terhadap pemahaman akuntansi Wajib Pajak UMKM, sehingga hipotesis ketujuh ditolak.

\section{Analisis Substruktural II \\ $\mathrm{Y}($ KEPATUHAN $)=\beta$ MORAL $+\beta$ FREKUENSI $+\beta$ NORMA $+\beta$ PEMAHAMAN $+e_{2}($ Persamaan Struktural 2) \\ Tabel 11 \\ Pengaruh Moral, Frekuensi Pelatihan Pelaporan Perpajakan,Norma Subjektif, Pemahaman Akuntansi Secara Simultan Terhadap Kepatuhan Pajak

\begin{tabular}{|l|l|}
\hline Model & R Square \\
\hline & 0,341 \\
\hline
\end{tabular} \\ Sumber: Data diolah dari lampiran, 2019}

Berdasarkan tabel 11 dapat diketahui bahwa nilai koefisien determinasi ditunjukkan dari besarnya angka $R$ Square $\left(\mathrm{R}^{2}\right)$ yang diperoleh adalah 0,341 . Hal ini dapat diartikan bahwa pengaruh variabel moral, frekuensi pelatihan pelaporan perpajakan, norma subjektif, dan pemahaman akuntansi terhadap variabel kepatuhan pajak secara simultan sebesar $34,1 \%$, sedangkan sisanya sebesar 65,9\% dipengaruhi oleh variabel lain di luar penelitian ini.

Untuk mengetahui kelayakan model regresi digambarkan angka-angka dari tabel ANOVA.

Tabel 12

ANOVA dengan nilai F dan Sig.

\begin{tabular}{|l|l|l|}
\hline Model & F & Sig. \\
\hline $\begin{array}{l}\text { Regression } \\
\text { Residual } \\
\text { Total }\end{array}$ & 12,308 & 0,000 \\
\hline
\end{tabular}

Sumber: Data diolah dari lampiran, 2019 
Jika F-hitung > F-tabel, maka Ho ditolak dan Ha diterima dan sebaliknya F-hitung < Ftabel, maka Ho diterima dan Ha ditolak. Dari hasil uji F pada tabel 13, diperoleh angka Fhitung sebesar 12,308 > F-tabel sebesar 2,47 dan signifikan dengan signifikansi 0,000<0,05, sehingga Ho ditolak dan Ha diterima. Dengan demikian, model regresi tersebut sudah layak dan benar. Kesimpulannya adalah variabel moral, frekuensi pelatihan pelaporan perpajakan, norma subjektif, dan pemahaman akuntansi mempunyai pengaruh yang signifikan secara simultan terhadap variabel kepatuhan pajak.

Tabel 13

Pengaruh Moral, Frekuensi Pelatihan Pelaporan Perpajakan, Norma Subjektif, Pemahaman Akuntansi Secara Parsial Terhadap Kepatuhan Pajak

\begin{tabular}{|l|l|l|l|}
\hline \multirow{2}{*}{ Model } & $\begin{array}{l}\text { Unstandardized } \\
\text { Coefficients }\end{array}$ & \multirow{2}{*}{$\mathrm{T}$} & \multirow{2}{*}{ Sig } \\
\cline { 2 - 3 } & Beta & 5,394 & 0,000 \\
\hline (Constant) & 21,952 & 2,616 & 0,010 \\
Moral & 0,497 & 0,184 & 0,854 \\
Frekuensi Pelatihan & 0,021 & 2,546 & 0,012 \\
Pelaporan Perpajakan & 0,440 & 2,308 & 0,023 \\
Norma Subjektif & 0,190 & & \\
Pemahaman Akuntansi & &
\end{tabular}

Sumber: Data diolah dari lampiran, 2019

Jika t-hitung > t-tabel, maka Ho ditolak dan Ha diterima dan sebaliknya t-hitung < ttabel, maka Ho diterima dan Ha ditolak. Besarnya angka t-tabel dengan ketentuan $\alpha=0,05$ dan $\mathrm{df}=(\mathrm{n}-\mathrm{k})$ atau $(100-5)=95$. Dari ketentuan tersebut diperoleh angka t-tabel sebesar 1,98525. Berikut hasil uji t berdasarkan tabel 14:

Pengaruh Moral Terhadap Kepatuhan Pajak Wajib Pajak UMKM. Berdasarkan hasil perhitungan, diperoleh angka t-hitung lebih besar dari t-tabel $(2,616>1,98525)$, menjelaskan bahwa moral berpengaruh terhadap kepatuhan pajak Wajib Pajak UMKM. Angka signifikansi pada variabel moral sebesar $0,010<0,05$. Atas dasar perbandingan tersebut, maka Ho ditolak dan Ha diterima, artinya variabel moral mempunyai pengaruh yang signifikan terhadap kepatuhan pajak Wajib Pajak UMKM, sehingga hipotesis pertama diterima.

Pengaruh Frekuensi Pelatihan Pelaporan Perpajakan Terhadap Kepatuhan Pajak Wajib Pajak UMKM. Berdasarkan hasil perhitungan, diperoleh angka t-hitung lebih kecil dari t-tabel $(0,184<1,98525)$, menjelaskan bahwa frekuensi pelatihan pelaporan perpajakan tidak berpengaruh terhadap kepatuhan pajak Wajib Pajak UMKM. Angka signifikansi pada variabel frekuensi pelatihan pelaporan perpajakan sebesar 0,854>0,05. Atas dasar perbandingan tersebut, maka Ho diterima dan Ha ditolak, artinya variabel frekuensi pelatihan pelaporan perpajakan tidak mempunyai pengaruh yang signifikan terhadap kepatuhan pajak Wajib Pajak UMKM, sehingga hipotesis kedua ditolak.

Pengaruh Norma Subjektif Terhadap Kepatuhan Pajak Wajib Pajak UMKM. Berdasarkan hasil perhitungan, diperoleh angka t-hitung lebih besar dari t-tabel $(2,546>$ 1,98525), menjelaskan bahwa norma subjektif berpengaruh terhadap kepatuhan pajak Wajib Pajak UMKM. Angka signifikansi pada variabel norma subjektif sebesar 0,012<0,05. Atas dasar perbandingan tersebut, maka Ho ditolak dan Ha diterima, artinya variabel norma subjektif mempunyai pengaruh yang signifikan terhadap kepatuhan pajak Wajib Pajak UMKM, sehingga hipotesis ketiga diterima.

Pengaruh Pemahaman Akuntansi Terhadap Kepatuhan Pajak Wajib Pajak UMKM. Berdasarkan hasil perhitungan, diperoleh angka t-hitung lebih besar dari t-tabel $(2,308>$ 1,98525), menjelaskan bahwa pemahaman akuntansi berpengaruh terhadap kepatuhan pajak 
Wajib Pajak UMKM. Angka signifikansi pada variabel pemahaman akuntansi sebesar 0,023 $<0,05$. Atas dasar perbandingan tersebut, maka Ho ditolak dan Ha diterima, artinya variabel pemahaman akuntansi mempunyai pengaruh yang signifikan terhadap kepatuhan pajak Wajib Pajak UMKM sehingga hipotesis keempat diterima.

\section{Analisis Pengujian Variabel Mediasi atau Intervening dengan Sobel Test}

Pengaruh Moral Terhadap Kepatuhan Pajak dengan Variabel Intervening Pemahaman Akuntansi

$>$ Koefisien antara variabel independen moral dan variabel intervening pemahaman akuntansi (A)

\section{Tabel 14}

Koefisien Moral Terhadap Pemahaman Akuntansi

\begin{tabular}{|c|c|}
\hline \multicolumn{1}{|c|}{ Model } & Coefficients \\
\hline Moral & 0.182 \\
\hline
\end{tabular}

Sumber: Data diolah dari lampiran, 2019

Koefisien antara variabel intervening pemahaman akuntansi dan variabel dependen kepatuhan pajak (B)

\section{Tabel 15}

Koefisien Pemahaman Akuntansi Terhadap Kepatuhan Pajak

\begin{tabular}{|c|c|}
\hline Model & Coefficients \\
\hline Pemahaman Akuntansi & 0.190 \\
\hline \multicolumn{2}{|c|}{ Sumber: Data diolah dari lampiran, 2019}
\end{tabular}

Standar eror dari A

Tabel 16

Standar Eror Moral Terhadap Pemahaman Akuntansi

\begin{tabular}{|c|c|}
\hline Model & Coefficients \\
\hline Moral & 0.234 \\
\hline \multicolumn{2}{|c|}{ Sumber: Data diolah dari lampiran, 2019 }
\end{tabular}

Standar eror dari B

Tabel 17

Standar Eror Pemahaman Akuntansi Terhadap Kepatuhan Pajak

\begin{tabular}{|c|c|}
\hline Model & Coefficients \\
\hline Pemahaman Akuntansi & 0.082 \\
\hline \multicolumn{2}{|c|}{ Sumber: Data diolah dari lampiran, 2019 }
\end{tabular}

Hasil analisis dengan Sobel Test Calculator for The Signification of Mediation Kris Preacher: Gambar 4

Analisis Intervening dengan Sobel Test X1 (Moral)

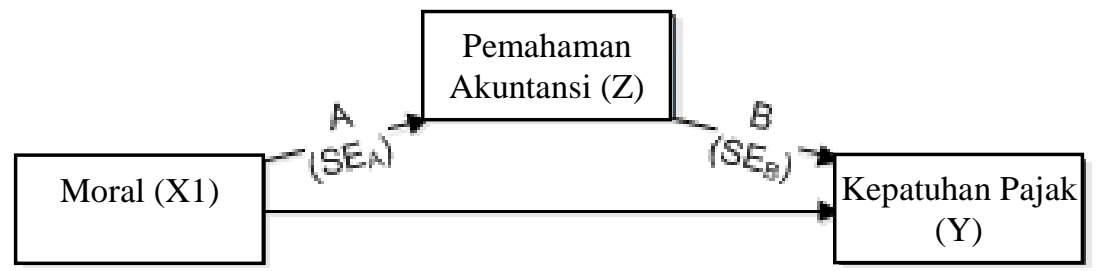

$\begin{array}{lr}\text { Sobel Test Statistic } & : 0.73734572 \\ \text { Two-tailed probability } & : 0.46091214 \\ \text { Sumber: Data diolah dari lampiran, } 2019\end{array}$

Berdasarkan hasil analisis dengan sobel test menunjukkan nilai statistik (z-value) untuk pengaruh variabel pemahaman akuntansi sebagai variabel intervening antara variabel moral dan kepatuhan pajak sebesar 0,73734572 dan nilai probabilitas ( -value) pada two-tailed probability sebesar 0,46091214. Karena $z$-value $<1,96$ atau $p$-value $>\alpha=0,05$, hal ini berarti bahwa pengaruh tidak langsung (indirect effect) variabel pemahaman akuntansi tidak 
berpengaruh dalam hubungan antara variabel moral terhadap variabel kepatuhan pajak. Atas dasar perbandingan tersebut, maka Ho diterima dan Ha ditolak, artinya moral tidak berpengaruh terhadap kepatuhan pajak melalui pemahaman akuntansi, sehingga hipotesis kedelapan ditolak.

Pengaruh Frekuensi Pelatihan Pelaporan Perpajakan Terhadap Kepatuhan Pajak dengan Variabel Intervening Pemahaman Akuntansi

$>$ Koefisien antara variabel independen frekuensi pelatihan pelaporan perpajakan dan variabel intervening pemahaman akuntansi (A)

Tabel 18

Koefisien Frekuensi Pelatihan Pelaporan Perpajakan Terhadap Pemahaman Akuntansi

\begin{tabular}{|l|c|}
\hline \multicolumn{1}{|c|}{ Model } & Coefficients \\
\hline $\begin{array}{l}\text { Frekuensi Pelatihan } \\
\text { Pelaporan Perpajakan }\end{array}$ & 0.313 \\
\hline
\end{tabular}

Sumber: Data diolah dari lampiran, 2019

Koefisien antara variabel intervening pemahaman akuntansi dan variabel dependen kepatuhan pajak (B)

Tabel 19

Koefisien Pemahaman Akuntansi Terhadap Kepatuhan Pajak

\begin{tabular}{|l|l|}
\hline Model & Coefficients \\
\hline Pemahaman Akuntansi & 0.190 \\
\hline
\end{tabular}

Sumber: Data diolah dari lampiran, 2019

Standar eror dari A

Tabel 20

Standar Eror Frekuensi Pelatihan Pelaporan Perpajakan Terhadap Pemahaman Akuntansi

\begin{tabular}{|l|c|}
\hline \multicolumn{1}{|c|}{ Model } & Coefficients \\
\hline $\begin{array}{l}\text { Frekuensi Pelatihan } \\
\text { Pelaporan Perpajakan }\end{array}$ & 0.139 \\
\hline
\end{tabular}

Sumber: Data diolah dari lampiran, 2019

Standar eror dari B

Tabel 21

Standar Eror Pemahaman Akuntansi Terhadap Kepatuhan Pajak

\begin{tabular}{|c|c|}
\hline Model & Coefficients \\
\hline Pemahaman Akuntansi & 0.082 \\
\hline \multicolumn{2}{|c|}{ Sumber: Data diolah dari lampiran, 2019 }
\end{tabular}

Hasil analisis dengan Sobel Test Calculator for The Signification of Mediation Kris Preacher: Gambar 5

Analisis Intervening dengan Sobel Test X2 (Frekuensi Pelatihan Pelaporan Perpajakan)

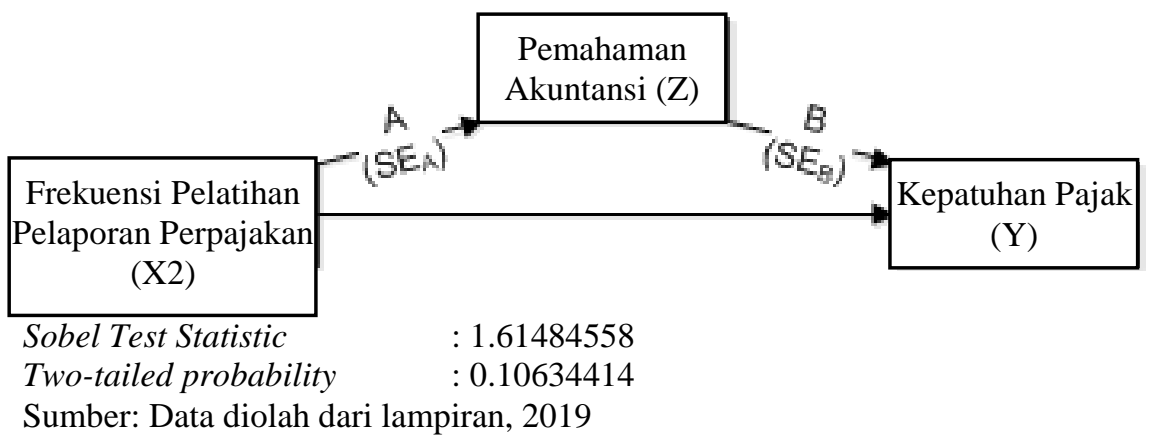

Berdasarkan hasil analisis dengan sobel test menunjukkan nilai statistik ( $z$-value) untuk pengaruh variabel pemahaman akuntansi sebagai variabel intervening antara variabel 
frekuensi pelatihan pelaporan perpajakan dan kepatuhan pajak sebesar 1.61484558 dan nilai probabilitas ( $p$-value) pada two-tailed probability sebesar 0.10634414 . Karena $z$-value $<1,96$ atau $p$-value $>\alpha=0,05$, hal ini berarti bahwa pengaruh tidak langsung (indirect effect) variabel pemahaman akuntansi tidak berpengaruh dalam hubungan antara variabel frekuensi pelatihan pelaporan perpajakan terhadap variabel kepatuhan pajak. Atas dasar perbandingan tersebut, maka Ho diterima dan Ha ditolak, artinya frekuensi pelatihan pelaporan perpajakan tidak berpengaruh terhadap kepatuhan pajak melalui pemahaman akuntansi, sehingga hipotesis kesembilan ditolak.

Pengaruh Norma Subjektif Terhadap Kepatuhan Pajak dengan Variabel Intervening Pemahaman Akuntansi

$>$ Koefisien antara variabel independen norma subjektif dan variabel intervening pemahaman akuntansi (A)

Tabel 22

Koefisien Norma Subjektif Terhadap Pemahaman Akuntansi

\begin{tabular}{|c|c|}
\hline Model & Coefficients \\
\hline Norma Subjektif & 0.399 \\
\hline \multicolumn{2}{|c|}{ Sumber: Data diolah dari lampiran, 2019}
\end{tabular}

Koefisien antara variabel intervening pemahaman akuntansi dan variabel dependen kepatuhan pajak (B)

Tabel 23

Koefisien Pemahaman Akuntansi Terhadap Kepatuhan Pajak

\begin{tabular}{|c|c|}
\hline Model & Coefficients \\
\hline Pemahaman Akuntansi & 0.190 \\
\hline \multicolumn{2}{|c|}{ Sumber: Data diolah dari lampiran, 2019}
\end{tabular}

Standar eror dari A

Tabel 24

Standar Eror Norma Subjektif Terhadap Pemahaman Akuntansi

\begin{tabular}{|c|c|}
\hline Model & Coefficients \\
\hline Norma Subjektif & 0.210 \\
\hline
\end{tabular}

Sumber: Data diolah dari lampiran, 2019

Standar eror dari B

Tabel 25

Standar Eror Pemahaman Akuntansi Terhadap Kepatuhan Pajak

\begin{tabular}{|c|c|}
\hline Model & Coefficients \\
\hline Pemahaman Akuntansi & 0.082 \\
\hline \multicolumn{2}{|c|}{ Sumber: Data diolah dari lampiran, 2019 }
\end{tabular}

Hasil analisis dengan Sobel Test Calculator for The Signification of Mediation Kris Preacher:

Gambar 6

Analisis Intervening dengan Sobel Test X3 (Norma Subjektif)

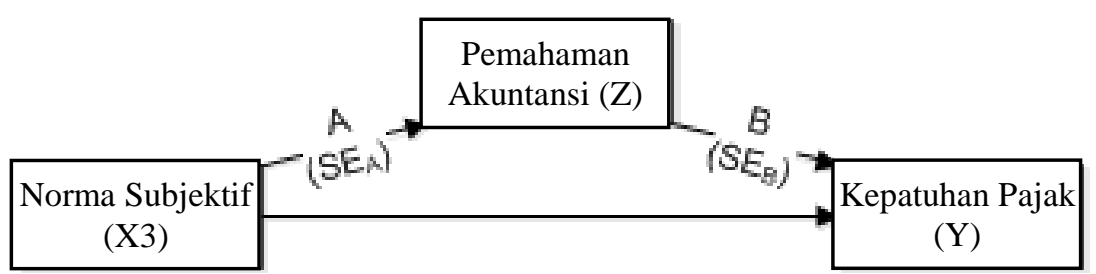

Sobel Test Statistik

: 1.46920880 
Two-tailed probability $\quad: 0.14177616$

Sumber: Data diolah dari lampiran, 2019

Berdasarkan hasil analisis dengan sobel test menunjukkan nilai statistik (z-value) untuk pengaruh variabel pemahaman akuntansi sebagai variabel intervening antara variabel norma subjektif dan kepatuhan pajak sebesar 1.46920880 dan nilai probabilitas ( $p$-value) pada twotailed probability sebesar 0.14177616. Karena $z$-value $<1,96$ atau $p$-value $>\alpha=0,05$, hal ini berarti bahwa pengaruh tidak langsung (indirect effect) variabel pemahaman akuntansi tidak berpengaruh dalam hubungan antara variabel norma subjektif terhadap variabel kepatuhan pajak. Atas dasar perbandingan tersebut, maka Ho diterima dan Ha ditolak, artinya norma subjektif tidak berpengaruh terhadap kepatuhan pajak melalui pemahaman akuntansi, sehingga hipotesis kesepuluh ditolak.

\section{Simpulan dan Saran}

Simpulan. Berdasarkan hasil penelitian mengenai pengaruh moral, frekuensi pelatihan pelaporan perpajakan, dan norma subjektif terhadap kepatuhan pajak melalui pemahaman akuntansi Wajib Pajak Usaha Mikro Kecil dan Menengah (UMKM) di KPP Pratama Cilegon, maka dapat disimpulkan sebagai berikut: (1) Moral berpengaruh signifikan terhadap kepatuhan pajak Wajib Pajak UMKM. (2) Frekuensi pelatihan pelaporan perpajakan tidak berpengaruh terhadap kepatuhan pajak Wajib Pajak UMKM. (3) Norma subjektif berpengaruh signifikan terhadap kepatuhan pajak Wajib Pajak UMKM. (4) Pemahaman akuntansi berpengaruh signifikan terhadap kepatuhan pajak Wajib Pajak UMKM. (5) Moral tidak berpengaruh terhadap pemahaman akuntansi Wajib Pajak UMKM (6) Frekuensi pelatihan pelaporan perpajakan berpengaruh terhadap pemahaman akuntansi Wajib Pajak UMKM (7) Norma subjektif tidak berpengaruh terhadap pemahaman akuntansi Wajib Pajak UMKM (8) Moral tidak berpengaruh terhadap kepatuhan pajak melalui pemahaman akuntansi Wajib Pajak UMKM. (9) Frekuensi pelatihan pelaporan perpajakan tidak berpengaruh terhadap kepatuhan pajak melalui pemahaman akuntansi Wajib Pajak UMKM. (10) Norma subjektif tidak berpengaruh terhadap kepatuhan pajak melalui pemahaman akuntansi Wajib Pajak UMKM.

Saran. Berdasarkan hasil penelitian ini mengenai pengaruh moral, frekuensi pelatihan pelaporan perpajakan, dan norma subjektif terhadap kepatuhan pajak melalui pemahaman akuntansi Wajib Pajak Usaha Mikro Kecil dan Menengah (UMKM) di KPP Pratama Cilegon, maka saran-saran yang dapat diberikan sebagai berikut: (1) Peran dari Kantor Pelayanan Pajak (KPP) Pratama sangat diperlukan guna meningkatkan kepatuhan perpajakan dengan menjaga hubungan yang baik antara fiskus dengan Wajib Pajak dan masyarakat dengan terus meningkatkan kepercayaan yang telah diberikan, agar Wajib Pajak tidak melakukan penghindaran pajak serta masyarakat tidak ragu dan bangga menjadi pembayar pajak.

(2) Bagi Wajib Pajak Usaha Mikro Kecil dan Menengah (UMKM) sebaiknya lebih meningkatkan moralitas perpajakannya serta pentingnya motivasi atau dukungan dari lingkungan sekitar untuk mematuhi perpajakan sesuai dengan ketentuan peraturan perundang-undangan perpajakan yang berlaku. Sehingga penerimaan pajak negara dari sektor UMKM akan terealisasi dan meningkat. (3) Bagi penelitian selanjutnya, diaharapkan dengan mengembangkan penelitian ini dengan cara mengkaji atau menambah variabel lainnya yang mempengaruhi kepatuhan pajak Wajib Pajak UMKM. Selain itu hendaknya penelitian selanjutnya, terkait dengan responden, diharapkan lebih fokus pada satu kelompok UMKM Apakah keapada kelompok mikro saja, kecil atau menengah saja. 


\section{DAFTAR PUSTAKA}

Agoes, Sukrisno. (2014). Akuntansi Perpajakan. Edisi 3. Jakarta: Salemba Empat.

Alm, J. \& Torgler. (2012). Do Ethnics Matter? Tax Complianceand Tax Morality. Tulane Economic Working Paper Series.

Anwar, R.A. (2015). Pengaruh Sosialisasi Perpajakan Terhadap Kepatuhan Perpajkaan Wajib Pajak Usaha Mikro Kecil dan Menengah (UMKM) di Surakarta dengan Pengetahuan Perpajakan sebagai Variabel Pemediasi. Skripsi,Program Studi Akuntani Fakultas Ekonomi dan Bisnis Universitas Sebelas Maret Surakarta.

Appah, E. \& Wosowei, E.C. (2016). Tax Compliance Intentions and the Behaviour of the Individual Taxpayer: Evidence from Nigeria. Research Journal of Finance and Accounting ISSN 2222-1697 (Paper) ISSN 2222-2847 (Online), 7(13).

Ardy, A.B.K. \& Damayanti, T.W. (2018). Indonesian Taxpayers' Compliance: A MetaAnalysis. Accounting and Finance Research, 7(3).

Asfa I, Esti Rizqiana \& Wahyu Meiranto. (2017). Pengaruh Sanksi Perpajakan, Pelayanan Fiskus, Pengetahuan dan Pemahaman Perpajakan, Kesadaran Perpajakan Terhadap Kepatuhan Wajib Pajak. Diponegoro Journal of Accounting, 6(3), 1-13.

Artana, M. B. (2014). Pengaruh Kecerdasan Emosional, KecerdasanSpiritual, dan Pemahaman Belajar terhadap Pemahaman Akuntansi. E-Journal S1 AK Universitas Pendidikan Sansha, 2(1).

Astuti, Tri \& Ingrid Panjaitan. (2018). Pengaruh Moral Wajib Pajak dan Demografi Wajib Pajak Terhadap Kepatuhan Wajib Pajak UMKM Dengan Sanksi Perpajakan Sebagai Pemoderasi. Media Akuntansi Perpajakan, 3(1), 58-73.

Bulutoding, Lince et.al. (2018). The Influence of Akhlaq to Tax Compliance Behavior, and Niyyah as Mediating Variable of Moslem Taxpayers in Malaysia. Scientific Research Journal (SCIRJ), 6 (1), 2201-2796.

Cahyonowati, Nur. (2011). Model Moral dan Kepatuhan Perpajakan: Wajib Pajak Orang Pribadi. JAAI, 15(2), 161-177.

Chrissanjaya, A. (2018). The Influence of Tax Morale and Tax Authority's Service Quality to Tax Compliance. South East Asia Journal of Contemporary Business, Economics and Law, 15(5).

Dartini \& Jati. (2016). Pemahaman Akuntansi, Transparasi, dan Akuntabilitas Pada Kepatuhan Wajib Pajak Badan. E-Jurnal Akuntansi Universitas Udayana, 17(3), 2447-2473.

Fella, A. M. (2014). Pengaruh Moral Pajak dan Budaya Pajak terhadap Kepatuhan Pajak (Survey pada KPP Pratama Badung Karees). Jurnal Universitas Komputer Indonesia.

Fahmi, H. (2016). Pengaruh Pengetahuan Perpajakan, Kualitas Pelayanan Pemerintah Daerah dan Kesadaran oleh Wajib Pajak Terhadap Kepatuhan Wajib Pajak Dalam Pembayaran Pajak Bumi dan Bangunan (Studi Empiris pada Kabupaten Belitung Timur). Universitas Muhammadiyah Yogyakarta.

Galib, A., Indrijawati, A \& Rasyid, S. (2018). The Effect Of Spirituality, Subjective Norms And Perceived Behavioral Control On Taxpayer Compliance. Journal of Research in Business and Management, 6(4), 1-7.

Ghozali, Imam. (2016). Aplikasi Analisis Multivariate dengan Program IBM SPSS 23. Semarang: Badan Penerbit - Universitas Diponegoro.

Hendri, Nedi. (2016). Faktor-Faktor Yang Memepengaruhi Kepatuhan Wajib Pajak Dalam Membayar Pajak Pada UMKM di Kota Metro”. AKUISISI, 12(1). 
Jap, Y. P. (2018). Kepatuhan Pajak, Norma Sosial Masyarakat, Penegakan Hukum, dan Moral Pajak Perusahaan Agro Pada Bursa Efek di Indonesia. Jurnal Muara Ilmu Ekonomi dan Bisnis, 2(1), 137 - 145.

Kristiaji. (2013). Memahami Ketidakpatuhan Pajak. Jakarta: Danny Darussalam Tax Centre.

Layli Yobapritika Putri. (2014). Pengaruh Sikap, Norma Subjektif, dan Kontrol Keperilakuan yang Dipersepsikan terhadap Kepatuhan Wajib Pajak Orang Pribadi di Kota Yogyakarta. Skripsi. Program Studi Akuntansi Fakultas Ekonomi Universitas Negeri Yogyakarta.

Listyowati, Yuli Chomsatu Samrotun, Suhendro. (2018). Faktor-Faktor yang Mempengaruhi Kepatuhan Wajib Pajak Dalam Membayar Pajak. Jurnal Riset Akuntansi dan Bisnis Airlangga, 3(1), 372-395.

Mandagi, C. (2014). Pengaruh Pemeriksaan Pajak Terhadap Tingkat Kepatuhan Wajib Pajak Badan Dalam Memenuhi Kewajiban Perpajakannya Pada KPP Pratama Manado. Jurnal EMBA.

Mardiasmo. (2016). Perpajakan Edisi Revisi Tahun 2016. Yogyakarta: Penerbit Andi.

Masruroh, S. \& Zulaikha. (2013). Pengaruh Kemanfaatan NPWP, Pemahaman Wajib Pajak, Kualitas Pelayanan, Sanksi Perpajakan Terhadap Kepatuhan Wajib Pajak. Diponegoro Journal Of Accounting, 2(4), 1-15.

Nurinasari, D. (2016). Faktor-Faktor yang Mempengaruhi Wajib Pajak Orang Pribadi dalam Pemenuhan Kewajiban Perpajakannya. Naskah Publikasi Universitas Muhammadiyah Surakarta.

Oladipupo, A. O., \& Obazee, U. (2016). Tax Knowledge, Penalties and TaxCompliance in Small and Medium Scale Enterprises in Nigeria. IBusiness, 2 (1), 1-9.

Olaoye, C. O. et.al. (2017). Tax Information, Administration and Knowledge on Tax Payers' Compliance of Block Moulding Firms in Ekiti State. Journal of Finance and Accounting, 5(4), 131-138.

Pemerintah Indonesia. (2008). Undang-Undang No. 20 Tahun 2008 tentang Usaha Mikro, Kecil, dan Menengah. Lembaran Negara RI Tahun 2008 No. 93. Jakarta: Sekretariat Negara.

Pemerintah Indonesia. (2008). Undang-Undang No. 36 Tahun 2008 tentang Pajak Penghasilan. Lembaran Negara RI Tahun 2008 No. 133. Jakarta: Sekretariat Negara.

Pemerintah Indonesia. (2009). Undang-Undang No. 16 Tahun 2009 tentang Ketentuan Umum dan Tata Cara Perpajakan. Lembaran Negara RI Tahun 2009 No. 62. Jakarta: Sekretariat Negara.

Pemerintah Indonesia. (2012). Peraturan Menteri Keuangan RI No. 74/PMK.03/2012 tentang Tata Cara Penetapan dan Pencabutan Penetapan Wajib Pajak dengan Kriteria Tertentu Dalam Rangka Pengembalian Pendahuluan Kelebihan Pembayaran Pajak. Berita Negara RI Tahun 2012 No. 525. Jakarta: Sekretariat Negara.

Purnaditya, R.R. \& Rohman, A. (2015). Pengaruh Pemahaman Pajak, Kualitas Pelayanan dan Sanksi Pajak Terhadap Kepatuhan Pajak". Diponegoro Journal Of Accounting, 4(4), $1-11$.

Rahayu, S.K. (2013). Perpajakan Indonesia: Konsep dan Aspek Formal. Yogyakarta: Graha Ilmu.

Sani, Ahmad \& Azwansyah Habibie. (2017). Pengaruh Moral Wajib Pajak, Sikap Wajib Pajak dan Norma Subjektif terhadap Kepatuhan Pajak melaluiPemahaman Akuntansi. Jurnal Ilman, 5(2), 80-96.

Saputra, W. (2016). Pengaruh Kepercayaan, Moral, dan Kekuasaan Pemerintah Terhadap Tingkat Kepatuhan Pajak dan Penggelapan Pajak (Studi Kasus Pada KPP Pratama 
Kebon Jeruk Dua). Skripsi, Program Studi Akuntani Fakultas Ekonomi dan Bisnis Universitas Sultan Ageng Tirtayasa Serang Banten.

Siregar, S. (2014). Metode Penelitian Kuantitatif Dilengkapi dengan Perbandingan Perhitungan Manual dan SPSS. Jakarta: Kencana.

Sugiyono. (2014). Metode Penelitian Pendidikan (Pendekatan Kuantitatif, Kualitatif Dan $R \& D)$. Bandung: Alfabeta.

.2015. Metode Penelitian Pendidikan (Pendekatan Kuantitatif, Kualitatif Dan $R \& D)$. Bandung: Alfabeta.

.2016. Metode Penelitian Pendidikan (Pendekatan Kuantitatif, Kualitatif Dan $R \& D)$. Bandung: Alfabeta.

2017. Metode Penelitian Pendidikan (Pendekatan Kuantitatif, Kualitatif Dan $R \& D)$. Bandung: Alfabeta.

Suwito, E. (2017). Menguji Faktor-Faktor yang Berpengaruh Terhadap Ketaatan Pajak. Jurnal AKSI (Akuntansi dan Sistem Informasi), 1.

Tambun, S. (2016). Anteseden Kepatuhan Wajib Pajak Orang Pribadi dan Moderasi Sosialisasi Perpajakan. Jurnal Media Akuntansi Perpajakan, 1(1).

Torgler, B \& Frey, B. S. (2007). Tax Morale and Conditional Cooperation. Journal of Comparative Economics, 35(1), 136-159.

Waluyo. (2017). Perpajakan Indonesia. Jakarta: Salemba Empat.

Wardani, D. K. \& Erma Wati. (2018). Pengaruh Sosialisasi Perpajakan Terhadap Kepatuhan Wajib Pajak dengan Pengetahuan Perpajakan sebagai Variabel Intervening (Studi Pada Wajib Pajak Orang Pribadi di KPP Pratama Kebumen). Jurnal Nominal, 7(1).

Wicaksono, Rivan Arif, Nazar, Mohamad Rafki, \& Kurnia. (2018). Pengaruh Sanksi Perpajakan, Kualitas Pelayanan, dan Pengetahuan Wajib Pajak Terhadap Kepatuhan Wajib Pajak. Jurnal e-Proceeding of Management, 5 (1), 820.

Widodo, S.E. (2015). Manajemen Pengembangan Sumber Daya Manusia. Yogyakarta: Pustaka Pelajar.

Winerungan, O. L. (2013). Sosialisasi Perpajakan, Pelayanan Fiskus dan Sanksi Perpajakan Terhadap Kepatuhan WPOP di KPP Manado dan KPP Bitung. Jurnal EMBA, 1 (3).

Wurianti, Exti Lusiani Ega. (2015). Analisis Faktor - Faktor Yang Mempengaruhi Kepatuhan Wajib Pajak di Wilayah KPP Pratama. Jurnal Ilmu dan Riset Akuntansi, 4(6).

Yolanda, Ega Pralin. (2017). Pengaruh Sikap dan Norma Subjektif Terhadap Niat Mahasiswa Untuk Bersaing Menghadapi Masyarakat Ekonomi Asean (MEA). Skripsi Fakultas Ekonomi dan Bisnis Universitas Lampung. 